\title{
Quality Traits of Scented Rice (Oryza sativa L.) Variety Influenced by Different Nutrient Packages in Chattisgarh
}

\author{
Dushyant Pandey ${ }^{*}$ and Shrikant Chitale \\ Indira Gandhi Krishi Vishwavidyalaya, Raipur - 492001, Chattisgarh, India \\ *Corresponding author
}

\section{A B S T R A C T}

Field Experiment was conducted at Research Farm IGKV., Raipur (C.G.) during kharif season of 2010 and 2011 to study the effect of organic, inorganic and integrated nutrient

Keywords

Cow dung manure, Crop composted residue, Quality parameters, Neem cake and Alkali spreading

Article Info

Accepted:

28 January 2018

Available Online:

10 February 2018 management in Quality traits of scented rice (Oryza sativa L.) variety. The soil of experimental field was 'Inceptisols, which was low in nitrogen, medium in available phosphorus and potassium. The experiment was laid out in randomized block design with three replication. The treatments consisted of Basmati type rice variety Kasturi comprising organic, inorganic and integrated nutrient management. Treatment $\mathrm{T}_{1}(50 \% \mathrm{RDF}+50 \% \mathrm{~N}$ $(\mathrm{CDM}), \mathrm{T}_{2}\left(100 \% \mathrm{~N}\left(\left(1 / 3^{\text {rd }}\right.\right.\right.$ each $\left.\mathrm{CDM}+\mathrm{NC}+\mathrm{CCR}\right) \mathrm{T}_{3}\left(100 \% \mathrm{~N}\left(1 / 3^{\text {rd }}\right.\right.$ each $\mathrm{CDM}+\mathrm{NC}+$ $\mathrm{CCR})+$ Green manure in rice $), \mathrm{T}_{4} 100 \% \mathrm{~N}\left(1 / 3^{\text {rd }}\right.$ each $\left.\mathrm{CDM}+\mathrm{NC}+\mathrm{CCR}\right)+$ Deep summer ploughing), $\mathrm{T}_{5}(50 \% \mathrm{~N}(\mathrm{CDM})+\mathrm{RP}+\mathrm{PSB}+$ Azospirillum $), \mathrm{T}_{6}\left(100 \% \mathrm{~N}\left(1 / 3^{\text {rd }}\right.\right.$ each $\mathrm{CDM}+\mathrm{NC}+\mathrm{CCR})+$ Azospirillum.+ PSB) and $\mathrm{T}_{7}(100 \% \mathrm{RDF})$. The results revealed that among different organic, inorganic and integrated nutrient management practices $100 \%$ inorganic treatment resulting higher hulling milling, head rice recovery, paddy grain, Brown rice length, breadth and $\mathrm{L} / \mathrm{B}$ ratio followed by integrated and organic nutrient treatments, whereas alkali speading value was highest in $T_{5}$ and lower in $T_{7}$, However length, breadth and L/B ratio of polished and cooked kernel were more in INM practise.

\section{Introduction}

Human selection down the ages has given preference to quality to cater to the needs of diverse rice based preparations. India is the traditional producer and exporter of basmati rice. Basmati rice is most preferred and therefore fetches a very high premium in both international and domestic markets. Food crops grown using organic inputs having less or no chemicals are being preferred over conventionally produced food by the consumers. Organic food as is self- explanatory needs large quantity of organic manures to supply nutrients in soil but on the contrary, there is a serious decline in organic matter in Indian soils particularly in arid, semi-arid and sub-humid climate.

Application of organic manure not only improves the soil organic carbon for sustaining the soil physical quality but also increases the soil P (Singh et al., 2007) the replacement of external inputs viz., chemical fertilizers by farm-derived organic inputs normally leads to a reduction in variable input 
costs under organic management. This approach restores soil health and productivity in long term (Mitra et al., 1992), and also results in gradual increment in the grain yield with use of organics over a period of time (Urkurkar et al., 2010).

In Chhattisgarh, by virtue of using less quantity of chemical fertilizers and pesticides and dependency upon naturally available sources of nutrients, producing organic food could have better opportunity towards high remuneration with premium price in market with inherent lesser cost advantage. Therefore, an experiment has been conducted to evaluate different organic inputs, nutrients sources as well as to compare the chemical and integrated nutrient management in rice.

\section{Materials and Methods}

Field experiment was carried out during Kharif season of 2010 and 2011 at the Research-cum-Instructional Farm, Indira Gandhi Krishi Vishwavidyalaya, Raipur (CG), which had adequate facilities for irrigation and drainage. The quality traits of Basmati type rice variety are as follows.

\section{Physical quality characters}

\section{Spikelet length (SL) and breadth (SB)}

Ten Spikelets were taken randomly and average length was recorded in mm. Similarly, average breadth was recorded from same sample in $\mathrm{mm}$.

Spikelet length: breadth ratio (Spikelet L/B ratio)

This was calculated by the following formula:

Spikelet L: B ratio $=\frac{\text { Length of spikelet }}{\text { Breadth of spikelet }}$

\section{Hulling, milling and head rice recovery (\%)}

Observations on hulling, milling and head rice recovery percentage were recorded on the basis of $100 \mathrm{~g}$ seed sample which was collected from each plot of each replication.

These samples were hulled and milled by stake huller and miller and the percentage of milling and head rice recovery was calculated (Govindaswamy and Ghosh, 1969).

\section{Paddy length and breadth (mm)}

Ten paddy were taken randomly and average length and breadth were recorded in $\mathrm{mm}$.

Paddy length: breadth ratio (Paddy L/B ratio)

It was calculated by the formula:

Paddy length: breadth ratio =

Length of paddy grain

Breadth of paddy grain

\section{Brown rice length and breadth $(\mathrm{mm})$}

Ten hulled rice grain were taken randomly and average length and breadth were recorded in $\mathrm{mm}$.

Brown rice length: breadth ratio (Brown rice $L / B$ ratio)

This was calculated by the following formula:

Length of Brown rice Length: Breadth ratio of brown rice = --------Breadth of Brown rice

\section{Kernel length (KL) and breadth (KB)}

Ten milled grains were taken randomly and average length and breadth were estimated in $\mathrm{mm}$. 
Kernel length: breadth ratio (Kernel L/B ratio)

This was calculated by the following formula:

Kernel $\mathrm{L} / \mathrm{B}$ ratio $=\frac{\text { Length of milled grain }}{\text { Breadth of milled grain }}$

\section{Kernel length and breadth after cooking}

Sample of $5 \mathrm{~g}$ milled rice was taken from each entry and was imbided in $12 \mathrm{ml}$ of distilled water for 10 minutes followed by cooking for 15 minutes. Then cooked rice kernels were transferred to petriplates covered with filter paper. Ten cooked rice kernels were taken and individually length and breadth was measured.

\section{Elongation ratio}

This was calculated by the following formula:

Elongation ratio $=\frac{\text { Length of cooked kernel }}{\text { Length of raw kernel. }}$

\section{Chemical quality characteristics}

\section{Alkali value (Gelatinized test)}

It was measured in terms of alkali disintegration using a ' 7 ' point numerical spreading scale as suggested by Little et al., (1958). Six milled rice kernels were evenly placed in petriplates containing 1.7 per cent $\mathrm{KOH}$ solution at $30 \pm 1{ }^{\circ} \mathrm{C}$ for 23 hours and the spreading scale was recorded.

\section{Results and Discussion}

\section{Quality characters}

\section{Length, Breadth and $L / B$ ratio}

Length and Breadth of paddy grain and polished kernel, L/B ratio of polished kernel and cooked kernel and elongation ratio did not influenced significantly due to various treatments. However, rest of other quality parameters significantly affected due to variation in different treatments. According to the data presented in table 1, the longest paddy grain, brown rice, polished kernel and cooked kernel were recorded under treatment $100 \%$ RDF. However from breadth point of view the highest breadth of paddy grain and brown rice were recorded under $\mathrm{T}_{1}(50 \% \mathrm{RDF}+50 \% \mathrm{~N}$ applied through CDM) whereas breadth of cooked kernel was higher under $\mathrm{T}_{7}$ i.e., full inorganic supply (Maske et al., 1997). The highest $\mathrm{L} / \mathrm{B}$ ratio of paddy grain and brown rice were recorded with $\mathrm{T}_{7}$.

The differences among inorganic and organic treatments and also integrated nutrient management were not significant which showed that there were equal effects of all these nutrients treatments on most of quality parameters. On comparison of inorganic, organic, and integrated nutrient management treatments, it was observed that breadth of paddy grain and brown rice, L/B ratio of cooked kernel and elongation ratio were relatively higher under integrated treatments $\left(\mathrm{T}_{1}\right)$ while other quality parameters were higher under inorganic fertilizer treatments $\left(\mathrm{T}_{7}\right)$

Hulling, milling, head rice recovery and alkali value

Quality parameters viz. hulling milling and head rice recovery percentage are presented in table 2, significantly higher hulling and milling percentage were recorded in treatment $\mathrm{T}_{7}(100 \% \mathrm{RDF})$ which was at par with $\mathrm{T}_{1}, \mathrm{~T}_{2}$, $\mathrm{T}_{3}, \mathrm{~T}_{4}$ and $\mathrm{T}_{6}$ over $\mathrm{T}_{5}(50 \% \mathrm{~N}(\mathrm{CDM})$ where it was recorded the lowest hulling and milling percentage. Accordingly, head rice recovery was significantly more under treatment $100 \%$ RDF, which was at par with $T_{1}$ and $T_{3}$, over rest of the treatments. 
Table.1 Paddy grain, Brown rice, Polished kernel, cooked kernel, elongation of rice as influenced by different organic, inorganic and integrated nutrient management (pooled 2 years)

\begin{tabular}{|c|c|c|c|c|c|c|c|c|c|c|c|c|c|c|}
\hline & Treatments & & addy grain & & & rown rice & & & ished kern & & & oked kern & & Elong- \\
\hline & & Length & Breadth & L/B & Length & Breadth & $\mathbf{L} / \mathbf{B}$ & Length & Breadth & $\mathbf{L} / \mathbf{B}$ & Length & Breadth & L/B & ation \\
\hline & & Mm & Mm & Ratio & $\mathbf{m m}$ & Mm & Ratio & Mm & $\mathbf{m m}$ & Ratio & $\mathbf{m m}$ & $\mathbf{m m}$ & Ratio & Ratio \\
\hline$\overline{T_{1}}$ & $50 \% \mathrm{RDF}+50 \% \mathrm{~N}(\mathrm{CDM})$ & 10.03 & 2.23 & 4.32 & 7.80 & 1.81 & 4.32 & 6.43 & 1.75 & 3.68 & 9.73 & 3.06 & 3.18 & 1.51 \\
\hline$\overline{\mathbf{T}_{2}}$ & $100 \% \mathrm{~N}\left(1 / 3^{\mathrm{rd}}\right.$ each CDM+NC + CCR $)$ & 10.20 & 2.05 & 4.36 & 7.70 & 1.77 & 4.36 & 6.20 & 1.74 & 3.57 & 9.44 & 3.03 & 3.12 & 1.52 \\
\hline$\overline{T_{3}}$ & $\mathrm{~T}_{2}+\mathrm{GM}$ in rice & 9.93 & 2.13 & 4.46 & 7.83 & 1.77 & 4.46 & 6.23 & 1.75 & 3.56 & 9.48 & 2.97 & 3.19 & 1.52 \\
\hline$\overline{\mathbf{T}_{4}}$ & $\mathrm{~T}_{2}+\mathrm{DSP}$ & 9.37 & 2.17 & 4.33 & 7.27 & 1.68 & 4.33 & 6.33 & 1.73 & 3.65 & 9.38 & 3.01 & 3.11 & 1.48 \\
\hline$\overline{T_{5}}$ & $50 \% \mathrm{~N}(\mathrm{CDM})+$ Azospirillum $+\mathrm{RP}+\mathrm{PSB}$ & 9.93 & 2.17 & 4.41 & 7.80 & 1.77 & 4.41 & 6.20 & 1.74 & 3.56 & 9.47 & 2.94 & 3.22 & 1.52 \\
\hline$T_{6}$ & $\mathrm{~T}_{2}+$ Azospirillum $+\mathrm{PSB}$ & 9.90 & 2.17 & 4.47 & 7.98 & 1.78 & 4.47 & 6.27 & 1.75 & 3.57 & 9.4 & 2.99 & 3.14 & 1.49 \\
\hline$\overline{T_{7}}$ & $100 \% \mathrm{RDF}$ & 10.30 & 2.10 & 4.71 & 8.07 & 1.72 & 4.71 & 6.57 & 1.76 & 3.73 & 9.79 & 3.09 & 3.17 & 1.49 \\
\hline & $\operatorname{Sem} \pm$ & 0.14 & 0.068 & 0.11 & 0.087 & 0.04 & 0.11 & 0.103 & 0.015 & 0.06 & 0.104 & 0.039 & 0.061 & 0.03 \\
\hline & $\mathrm{CD}(\mathrm{P}=.05)$ & 0.44 & NS & 0.35 & 0.264 & 0.122 & 0.35 & 0.313 & NS & NS & 0.315 & 0.121 & NS & NS \\
\hline & & & & & Compa & ison & & & & & & & & \\
\hline 100 & inorganic fertilizers $\left(T_{7}\right)$ & 10.30 & 2.10 & 4.71 & 8.07 & 1.72 & 4.71 & 6.57 & 1.76 & 3.73 & 9.79 & 3.09 & 3.17 & 1.49 \\
\hline Int & rated nutrient management $\left(\mathrm{T}_{1}\right)$ & 10.03 & 2.23 & 4.32 & 7.80 & 1.81 & 4.32 & 6.43 & 1.75 & 3.68 & 9.73 & 3.06 & 3.18 & 1.51 \\
\hline 100 & organic fertilizer-mean of $\left(\mathrm{T}_{2}+\mathrm{T}_{3}+\mathrm{T}_{4}+\mathrm{T}_{6}\right)$ & 9.85 & 2.13 & 4.41 & 7.70 & 1.75 & 4.41 & 6.26 & 1.74 & 3.59 & 9.43 & 3.00 & 3.14 & 1.50 \\
\hline 50 & organic fertilizer $\left(T_{5}\right)$ & 9.93 & 2.17 & 4.41 & 7.80 & 1.77 & 4.41 & 6.20 & 1.74 & 3.56 & 9.47 & 2.94 & 3.22 & 1.52 \\
\hline & Overall Mean & 9.95 & 2.15 & 4.44 & 7.77 & 1.75 & 4.43 & 6.31 & 1.74 & 3.61 & 9.52 & 3.01 & 3.16 & 1.50 \\
\hline
\end{tabular}


Table. 2 Hulling and milling percentage, head rice recovery and alkali value of rice as influenced by different organic, inorganic and integrated nutrient management (pooled 2 years)

\begin{tabular}{|c|c|c|c|c|c|}
\hline \multicolumn{2}{|c|}{ Treatment } & $\begin{array}{l}\text { Hulling } \\
\text { percentage }\end{array}$ & $\begin{array}{l}\text { Milling } \\
\text { percentage }\end{array}$ & $\begin{array}{l}\text { Head rice } \\
\text { recovery }\end{array}$ & $\begin{array}{l}\text { Alkali } \\
\text { value GT }\end{array}$ \\
\hline $\mathbf{T}_{1}$ & $50 \% \mathrm{RDF}+50 \% \mathrm{~N}(\mathrm{CDM})$ & 78.83 & 63.54 & 61.16 & 4.32 \\
\hline $\mathrm{T}_{2}$ & $\begin{array}{l}100 \% \mathrm{~N}\left(1 / 3^{\text {rd }} \text { each }\right. \\
\mathrm{CDM}+\mathrm{NC}+\mathrm{CCR})\end{array}$ & 76.67 & 61.50 & 58.33 & 4.20 \\
\hline $\mathbf{T}_{3}$ & $\mathrm{~T}_{2}+\mathrm{GM}$ in rice & 78.33 & 63.16 & 59.91 & 4.25 \\
\hline $\mathbf{T}_{4}$ & $\mathrm{~T}_{2}+\mathrm{DSP}$ & 77.33 & 61.97 & 56.61 & 4.13 \\
\hline$\overline{T_{5}}$ & $\begin{array}{l}50 \% \mathrm{~N}(\mathrm{CDM})+\text { Azospirillum+ } \\
\mathrm{RP}+\mathrm{PSB}\end{array}$ & 74.89 & 60.81 & 53.81 & 4.38 \\
\hline$T_{6}$ & $\mathrm{~T}_{2}+$ Azospirillum $+\mathrm{PSB}$ & 77.62 & 62.50 & 58.67 & 4.43 \\
\hline $\mathbf{T}_{7}$ & $100 \% \mathrm{RDF}$ & 79.15 & 63.58 & 63.66 & 4.23 \\
\hline \multicolumn{2}{|c|}{ SEm \pm} & 1.16 & 0.88 & 1.37 & 0.12 \\
\hline \multicolumn{2}{|c|}{ C.D. $(P=0.05)$} & 3.53 & 2.69 & 4.16 & NS \\
\hline \multicolumn{6}{|c|}{ Comparison } \\
\hline \multicolumn{2}{|c|}{$100 \%$ inorganic fertilizers $\left(T_{7}\right)$} & 79.15 & 63.58 & 63.66 & 4.23 \\
\hline \multicolumn{2}{|c|}{$\begin{array}{l}\text { Integrated nutrient management } \\
\left(\mathrm{T}_{1}\right)\end{array}$} & 78.83 & 63.54 & 61.16 & 4.32 \\
\hline \multicolumn{2}{|r|}{$\begin{array}{l}100 \% \text { organic fertilizer- mean of } \\
\left(T_{2}+T_{3}+T_{4}+T_{6}\right)\end{array}$} & 77.48 & 62.28 & 58.38 & 4.25 \\
\hline \multicolumn{2}{|c|}{$\begin{array}{l}50 \% \text { organic fertilizer }\left(\mathrm{T}_{5}\right)+\text { Azos. } \\
+\mathrm{RP}+\text { PSB }\end{array}$} & 74.89 & 60.81 & 53.81 & 4.38 \\
\hline \multicolumn{2}{|c|}{ Overall mean } & 77.55 & 62.55 & 59.25 & 4.29 \\
\hline
\end{tabular}

\section{Seven point numerical spreading scale}

Score

$1 \quad-\quad$ Kernel not affected

2

3

4

5

6

7

\section{Spreading}

Kernel swollen
Kernel swollen, collar complete and narrow

Kernel swollen, collar complete and wide

Kernel split or segregated collar complete and wide

Kernel dispersed merging with collar

Kernel completely dispersed. 
However treatment $\mathrm{T}_{5}$ i.e. $(50 \% \mathrm{~N}$ applied through $\mathrm{CDM}$ ) recorded the minimum head rice recovery, whereas the Alkali spreading value did not differed significantly. On an average, $100 \%$ inorganic treatment resulting higher hulling milling and head rice recovery followed by integrated and organic fertilizer treatments. This result was in conformity with findings of Subhash et al., (1996).

\section{References}

Govindaswamy, S. and Ghosh, A.K. 1969. Time of harvest, moisture content and method of drying on milling quality of rice, Oryza 6(2): 54-66.

Little, R.R., Hilder, G.B. and Dawson, E.H. 1958. Differential effect of dilute alkali on 25 varieties of milled white rice. Cereal chemistry. 35:111-126.

Maske, N.S., Borkar, S.L. and Rajgire, H.J. 1997. Effects of nitrogen levels on growth, yield and grain quality of rice. Journal of Soils and Crops 7(1):83-86.

Mitra, G.N., Sahu, S.K. and Parida, S.K.1992. Integrated nutrient management of rice
(Oryza sativa) - groundnut (Arachis hypogaea) cropping system in Agric Haploquepts. Indian Journal of agricultural sciences, 62 (6): 391 - 394.

Singh, Y.V., B.V., Pabbi, S. and Singh, P.K. 2007. Impact of organic farming on Yield and quality of basmati rice and soil properties. Paper presented at Zwischen Tradition und Globalisierung - 9. Wissenschaftstagung Okologischer Landbau, Universitat Hohenheim, Stuttgart, Deutschland, Germany, during 20-23 March 2007.

Subhash, H. and Beser, N. 1996. A research to determine the suitable rice (Oryza sativa L.) Harvesting time. Turkish Journal of Agricultural forestry. 22(4): 391-394.

Urkurkar, J.S., Tiwari, A, Chitale, S. and Bajpai, R.K. 2010. Influence of long term use of inorganic and organic manures on soil fertility and sustainable productivity of rice (Oryza sativa)wheat (Triticum aestivum) in inceptisols. Indian Journal of Agricultural Sciences, 80(3): 208-212.

\section{How to cite this article:}

Dushyant Pandey and Shrikant Chitale. 2018. Quality Traits of Scented Rice (Oryza sativa L.) Variety Influenced by Different Nutrient Packages in Chattisgarh. Int.J.Curr.Microbiol.App.Sci. 7(02): 3589-3594. doi: https://doi.org/10.20546/ijcmas.2018.702.427 